\title{
ENVIRONMENTAL STRATIFICATION OF THE CORN SECOND SEASON ON THE WEST AND MID-WESTERN OF PARANÁ
}

\author{
Adilson Ricken Schuelter ${ }^{1 *}$, (D) Jonatas Marcolin²; (iD Talles de Oliveira
} Santos $^{3}$, (iD Debora Pereira ${ }^{1}$, (iD) Hugo Zeni Neto ${ }^{4}$, (D) Lucimar Pereira Bonett ${ }^{5}$, (iD) Ivan Schuster ${ }^{6}$

1 Faculdade Educacional de Medianeira (UDC Medianeira), Medianeira, PR, 85884-000;

2 Corteva Agriscience, Toledo, PR, 85970-000;

3 Laboratório de Melhoramento Genético Vegetal, Universidade Estadual do Norte Fluminense

Darcy Ribeiro (UENF), Campos dos Goytacazes, RJ, 28013-602;

4 Universidade Estadual de Maringá (UEM), Maringá, PR, 87020-900;

5 Universidade Paranaense (UNIPAR), Umuarama, PR, 87502-210;

6 Longping High-Tech, Cravinhos, SP, 14140-000.

*Corresponding author: Adilson Ricken Schuelter (adilson_schuelter@yahoo.com.br).

\begin{abstract}
Maize is the main crop of Paraná State second season, however the heterogeneity of the environmental conditions creates a challenge for the selection of adapted superior genotypes. The objective of this study was to stratify the environments of the Western and Mid-western mesoregions, to identify the environments that are essential for the selection of genotypes to ensure yield and crop moisture. Data sets regarding the yield and crop moisture of 16 commercial hybrids were used, sourced from Cooperativa Central de Pesquisa Agrícola (COODETEC) Value for Cultivation and Use ("VCU"), testing in a randomized complete block design with two replicates, of crops grown in the interim-harvests of 2014 and 2015 in the west of Paraná, in the Cascavel, Toledo and Foz do Iguaçu microregions, the Mid-western Campo Mourão microregion and Mariluz, constituting the Caiuá sandstone formation. The evaluation of the representativeness of the environments was carried out over one year of study, through environmental stratification analysis, using the factor analysis methodology. The results of the environmental stratification demonstrated that trials in the same environment provide redundant results, both for yield and for crop moisture. There were no gains for the selection of superior genotypes and the positioning in the different microregions yielded complementary data, aiding the selection. As such, for the West and West Central regions of Paraná, the Cascavel, Palotina, Mariluz, Campo Mourão and São Pedro do Iguaçu municipalities are indispensable for selection for yield and the Campo Mourão, Cascavel, Mariluz, Santa Terezinha do Itaipu, Palotina and São Pedro do Iguaçu municipalities are indispensable for selection for crop humidity.
\end{abstract}

Keywords: Factor analysis, multivariate analysis, Murakami and Cruz method. 


\section{Introduction}

The West and the Central West of Paraná are responsible for $49 \%$ of all production of second-crop corn cultivated in the State (SEAB/ DERAL, 2019) and are characterized by high altitude areas with frequent and severe frost and low altitude areas with high temperatures and with infrequent frosts (IPARDES, 2003; 2004a). In part of the low-lying area of the Midwest mesoregion there are soils from Caiuá sandstone, present in $16 \%$ of the state territory, where the climate resembles the Northwest mesoregion (IPARDES, 2004b; Melotto et al., 2019).

The second-crop corn, or 'safrinha', of Paraná is usually sown after summer soybean cultivation and its yield can be affected by solar radiation and temperature limitations (Sans and Guimarães, 2006; Batista et al., 2019) and, for this reason, early planting by using early soybean cultivars provides better climate conditions for corn development, increasing yield (Shioga and Gerage, 2010). In areas of higher altitudes, limited by low temperatures and frost, hybrids with lower thermal demands have allowed the second-crop expansion (Bergamaschi and Matzenauer, 2009).

The heterogeneity of climatic conditions makes selection difficult due to genotype $\times$ environment interaction (Shioga et al., 2015). The studies of genotype $\times$ environment interaction are of fundamental importance in a breeding program because they allow to minimize the effects of interaction (Ribeiro and Almeida, 2011), by selecting consistent genotypes for different environments, since the stability of genotypes is so important as the high productive potential (Martinelli et al., 2012).

For the selection of consistent genotypes, the experimental areas should represent the different conditions of the region under study. It is essential to identify whether there are environments of similar or complementary patterns (Pereira et al., 2010), thus reducing the number of environments without generating losses in the selection process (Mendonça et al., 2007; Mendes and Ramalho, 2018). Thus, the identification of the similarity or complementarity of environments is mad through enviromental stratificatio.
The factor analysis of Murakami and Cruz (2004) uses the principle of similarity of genotypic performance based on multivariate techniques, reducing a large number of original variables to a smaller number of abstract variables called factors. In each factor, environments are linearly correlated and weakly correlated with those grouped in the other factors (Garbuglio et al., 2007), generating not only two groups of environments (favorable and unfavorable), which is a questionable fact for other methodologies (Cruz and Carneiro, 2006). Factor analysis has been used by several authors for studies of environmental adaptability and stratification (Garbuglio et al., 2007; Mendonça et al., 2007; Pereira et al., 2013; Carvalho et al., 2014; Mendes and Ramalho, 2018).

The objective of this study was to stratify second-crop environments of the West and Central West mesoregions to identify informative environments for the selection of maize genotypes for yield and crop moisture (precocity).

\section{Material and methods}

Eighteen experiments of Value of Cultivation and Use (VCU) of the Cooperativa Central de Pesquisa Agrícola - COODETEC were evaluated, being half in the second season of 2014 and the others in the subsequent year (2015). The experiments in the West Paraná mesoregion were carried out in the Cascavel (Cascavel 1 and 2), Toledo (São Pedro do Iguaçu, Palotina 1 and 2) and Foz do Iguaçu (Santa Terezinha do Itaipu) microregions. In the Central West Paraná region, the experiments were conducted in the Campo Mourão (Campo Mourão) and Mariluz (Mariluz 1 and 2) microregions, which represent the lower areas of the Central West Center, and part of the northwest where Caiuá sandstone soils occur (Table 1).

Second-crop climate 2014 was characterized by irregularities in rainfall, concentrating large volumes of rain in short periods and sharp drops in temperature, but no frosts were recorded (Shioga et al., 2014). In second-crop 2015, in addition to not having frosts, the maximum and minimum temperatures were higher compared to the historical average during the corn cycle, which favored crop development (Shioga et al., 2015). 
Table 1. Hybrid evaluation trial conduction sites in the 2014 and 2015 second-crop in West and Central West of Paraná.

\begin{tabular}{|c|c|c|c|c|c|c|}
\hline \multicolumn{7}{|c|}{ Season 2014} \\
\hline Mesoregion & Microregion & Municipality & Assay & Altitude (m) & Sowing & Harvest \\
\hline Central West & Campo Mourão & Campo Mourão & 1 & 651 & $26 / 02 / 2014$ & $28 / 07 / 2014$ \\
\hline West & Cascavel & Cascavel & 2 & 667 & $11 / 02 / 2014$ & $10 / 07 / 2014$ \\
\hline West & Cascavel & Cascavel & 3 & 667 & $11 / 02 / 2014$ & $10 / 07 / 2014$ \\
\hline Northwest & Umuarama & Mariluz & 4 & 405 & $13 / 02 / 2014$ & $02 / 07 / 2014$ \\
\hline Northwest & Umuarama & Mariluz & 5 & 405 & $13 / 02 / 2014$ & $02 / 07 / 2014$ \\
\hline West & Toledo & Palotina & 6 & 370 & $13 / 02 / 2014$ & $27 / 06 / 2014$ \\
\hline West & Toledo & Palotina & 7 & 373 & $17 / 02 / 2014$ & $12 / 07 / 2014$ \\
\hline West & Foz do Iguaçu & Santa Teresinha do Itaipu & 8 & 264 & $11 / 02 / 2014$ & $22 / 07 / 2014$ \\
\hline West & Toledo & São Pedro do Iguaçu & 9 & 523 & $16 / 02 / 2014$ & $25 / 07 / 2014$ \\
\hline
\end{tabular}

\begin{tabular}{lllcccc}
\hline & \multicolumn{2}{c}{ Season $\mathbf{2 0 1 5}$} \\
Mesoregion & Microregion & Municipality & Assay & Altitude $(\mathbf{m})$ & Sowing & Harvest \\
\hline Central West & Campo Mourão & Campo Mourão & 10 & 628 & $02 / 03 / 2015$ & $13 / 08 / 2015$ \\
\hline West & Cascavel & Cascavel & 11 & 657 & $02 / 02 / 2015$ & $06 / 07 / 2015$ \\
\hline West & Cascavel & Cascavel & 12 & 657 & $02 / 02 / 2015$ & $06 / 07 / 2015$ \\
\hline Northwest & Umuarama & Mariluz & 13 & 415 & $22 / 02 / 2015$ & $03 / 08 / 2015$ \\
\hline Northwest & Umuarama & Mariluz & 14 & 415 & $22 / 02 / 2015$ & $03 / 08 / 2015$ \\
\hline West & Toledo & Palotina & 15 & 362 & $18 / 02 / 2015$ & $29 / 06 / 2015$ \\
\hline West & Toledo & Palotina & 16 & 362 & $18 / 02 / 2015$ & $29 / 06 / 2015$ \\
\hline West & Foz do Iguaçu & Santa Teresinha do Itaipu & 17 & 264 & $10 / 02 / 2015$ & $23 / 07 / 2015$ \\
\hline West & Toledo & São Pedro do Iguaçu & 18 & 510 & $12 / 02 / 2015$ & $23 / 07 / 215$ \\
\hline
\end{tabular}

The experiments consisted of 50 hybrids (commercial, pre-commercial and experimental) from which 16 commercial hybrids were selected, 10 single hybrids and 6 triple hybrids, present in all trials in the two years of evaluation for this study. The experimental design was complete blocks with randomized treatments, containing two replications. The experimental unit consisted of two rows of 5 meters with 0.76 $\mathrm{m}$ row spacing, with final population of 60,000 plants $\mathrm{ha}^{-1}$, adjusted by thinning, carried out between the phenological stages V3 and V5 of each assay (Da Rocha, 2011).

Harvesting and determination of harvest moisture were performed in total plot, with harvester adapted to harvest plots. The raw weight data were transformed into $\mathrm{kg} \mathrm{ha}^{-1}$ for yield adjusted to $14 \%$ humidity. Data from each assay were subjected to individual variance analysis and Hartley's maximum F test (1950) to verify homogeneity of residual variances. For the analysis of joint variance was used correction of the homogeneity of residual variances of the tests that did not present homogeneity by Hartley's maximum $F$ test (1950) through the Cochran methodology (1954), allowing the joint analysis of all environments of each crop.
The environmental stratification was performed using the factor analysis method proposed by Murakami and Cruz (2004). For the definition of the final factor numbers, the recommendation of Cruz and Carneiro (2006) was followed, which states that the number of final factors is equal to the number of eigenvalues greater than 1 in the phenotypic correlation matrix or until an adequate proportion of total variability is obtained, usually greater than $80 \%$. This pattern has been used by several researchers (Granate et al., 2001; Murakami and Cruz, 2004; Cruz and Carneiro, 2006; Garbuglio et al., 2007; Mendonça et al., 2007; Carvalho et al., 2014).

The final number of factors defined for each set was used to generate the final factor loads after rotation by the principal component method. The grouping of the environments was performed as described by Johnson and Wichern (1992), who state that final factor loads equal to or greater than 0.70 and of the same signal indicate environments with a high similarity standard and can be grouped within each factor. All the genetic-statistical analyzes were performed using the software Genes (Cruz, 2013). 


\section{Results and discussion}

Only the harvesting moisture variable of 2015 second-crop corn showed no homogeneity of residual variances by Barttlett's test and normality by Lilliefors. The data were corrected for the degrees of freedom of the residue and the genotype $\times$ environment interaction, according to the method of Cochran (1954), allowing the joint analysis.

The joint variance analysis was performed within each year of evaluation. The coefficients of variation were classified as low and medium, according to the criteria proposed by Scapim et al. (1995) and Pimentel-Gomes (2009), allowing to conclude that the experimental precision is acceptable, being adequate for analysis in different years (Table 2).

For yield in 2014 second-crop and crop moisture in 2014 and 2015 second-crop, significance was found at $1 \%$ probability for the sources of variation Environments (E) and genotype $\times$ environment interaction $(\mathrm{G} \times \mathrm{E})$ by the
F test (Table 2). The high significance of the $\mathrm{G} \times \mathrm{E}$ interaction indicates different behavior of genotypes due the environmental variations. The evaluation of this interaction is important because a genotype can stand out in some places and not in others (Faria et al., 2009). The presence of $\mathrm{G} \times \mathrm{E}$ may result in low correlation between phenotypic and genotypic values, thus reducing the progress of selection. This leads to a bias in estimating heritability and predicting genetic advance (Dia et al., 2016).

The study of $\mathrm{G} \times \mathrm{E}$ interaction behavior justifies the realization of environmental stratification (Cruz and Carneiro, 2006; Pereira et al., 2010). In 2015 second-crop, the yield variable was not significant for the $G \times E$ interaction, however, the source of variation Environments was significant at $5 \%$ by the $\mathrm{F}$. Pereira et al. (2010) state that if significant differences between sites are detected, this highlights the possibility of performing environmental stratification analyzes, as it indicates that there is variability between sites.

Table 2. Summary of joint variance analysis for productivity and crop humidity in second-crop corn hybrids in West and Central West of Paraná, in 2014 and 2015.

\begin{tabular}{|c|c|c|c|c|c|}
\hline & \multirow{2}{*}{ SV } & \multicolumn{2}{|c|}{2014} & \multicolumn{2}{|c|}{2015} \\
\hline & & DF & MS & DF & MS \\
\hline \multirow{7}{*}{ Yield $\left(\mathrm{kg} \mathrm{ha}^{-1}\right)$} & Blocks/ Environments & 9 & 639107.10 & 9 & 2489136.50 \\
\hline & Genotype (G) & 15 & $1858990.40^{\text {ns }}$ & 15 & $10240252.30 * *$ \\
\hline & Environment (E) & 8 & $41040152.60 * *$ & 8 & $11194712.30^{*}$ \\
\hline & G×E & 120 & $1259538.40^{* *}$ & 120 & $1900651.40^{\text {ns }}$ \\
\hline & Error & 135 & 541561.80 & 135 & 1934353.50 \\
\hline & Mean & 7297.09 & & 7693,94 & \\
\hline & CV (\%) & 10.09 & & 18,08 & \\
\hline \multirow{7}{*}{$\begin{array}{l}\text { harvest } \\
\text { moisture (\%) }\end{array}$} & Blocks/ Environments & 9 & 9.12 & 9 & 2.97 \\
\hline & Genotype (G) & 15 & $128.93 * *$ & 15 & $171.44^{* *}$ \\
\hline & Environment (E) & 8 & $417.23 * *$ & 8 & $634.50 * *$ \\
\hline & G×E & 120 & $16.28 * *$ & 83 & $13.33 * *$ \\
\hline & Error & 135 & 4.77 & 90 & 4.76 \\
\hline & Mean & 25.81 & & 22.24 & \\
\hline & CV (\%) & 8.46 & & 9.81 & \\
\hline
\end{tabular}

Environmental stratification and phenotypic adaptability can be studied using factor analysis. In order to apply the information obtained by factor analysis, it is crucial that each variable considered can be adequately represented by common factors, those that will provide values that allow inference on the strata of the environment and on the adaptability of the studied genotypes (Sousa et al., 2015).
All communalities were above 0.64 (Table 3 ), which shows high efficiency in the representation of variables by a common part (Mendonça et al., 2007) and has been considered as an acceptable value, as it would be equivalent to the correlation coefficient greater than 0.80 between the standard variable and the common part explaining this variable. The high communalities show factoring quality for the 
grouping of environments and small specific variance (Resende, 2015).

For 2014 second-crop yield, 5 factors were considered, capturing $84.88 \%$ of the variability. In each of the five factors was isolated an environment, Campo Mourão, Cascavel 2, Santa Terezinha do Itaipu, Cascavel 1 and Palotina 1, in factors 1, 2, 3, 4 and 5, respectively, indicating low correlation between them and that are potential complementary information generators for selection for productivity (Table 3).

For yield in 2015 second-crop were considered 4 factors, which captured $81.18 \%$ of the variability. Factor 1 grouped the environments Cascavel 1 and São Pedro do Iguaçu, affirming proximity of response between them. Factor 3 grouped the environments Campo Mourão and Cascavel 2 indicating correlation of results. Factor 4 grouped the Palotina 1 and Palotina 2 assays, and similarly, in factor 2 the Mariluz 1 and Mariluz 2 environments were grouped. Pereira et al. (2013) report similar results, where in a single factor grouped two trials conducted in the same municipality, according to them, shown reliability of the analysis. Fritsche-Neto et al. (2010), when stratifying nine environments, showed that two of the factors studied grouped together two environments in the same municipality, probably due to soil and climatic homogeneity as a result of their geographical proximity, similar altitude and location in the hills.

Table 3. Environmental stratification, according to the factor analysis methodology, for yield of corn hybrids in the 2014 and 2015 second-crop in West and Central West of Paraná.

\begin{tabular}{|c|c|c|c|c|c|c|c|}
\hline Season & Environment & Factor 1 & Factor 2 & Factor 3 & Factor 4 & Factor 5 & Communalities \\
\hline \multirow{9}{*}{2014} & Campo Mourão & 0.849 & -0.002 & -0.186 & 0.071 & 0.144 & 0.781 \\
\hline & Cascavel 1 & 0.390 & 0.284 & -0.017 & 0.869 & -0.188 & 0.929 \\
\hline & Cascavel 2 & 0.003 & 0.955 & 0.004 & 0.168 & -0.042 & 0.941 \\
\hline & Mariluz 1 & 0.041 & 0.360 & -0.692 & 0.051 & -0.398 & 0.771 \\
\hline & Mariluz 2 & -0.417 & -0.167 & -0.610 & 0.578 & 0.074 & 0.913 \\
\hline & Palotina 1 & 0.239 & -0.085 & 0.079 & -0.177 & 0.900 & 0.911 \\
\hline & Palotina 2 & 0.608 & 0.331 & 0.310 & 0.140 & 0.518 & 0.864 \\
\hline & Sta. Terezinha do Itaipu & -0.105 & 0.145 & 0.849 & -0.052 & -0.002 & 0.756 \\
\hline & S. Pedro do Iguaçu & 0.563 & -0.243 & 0.551 & 0.093 & 0.290 & 0.772 \\
\hline \multirow{9}{*}{2015} & Campo Mourão & 0.175 & -0.074 & 0.832 & -0.255 & & 0.793 \\
\hline & Cascavel 1 & 0.807 & -0.050 & 0.143 & -0.374 & & 0.814 \\
\hline & Cascavel 2 & 0.265 & 0.206 & 0.850 & -0.209 & & 0.878 \\
\hline & Mariluz 1 & 0.254 & 0.731 & -0.277 & -0.171 & & 0.705 \\
\hline & Mariluz 2 & -0.349 & 0.798 & 0.211 & -0.039 & & 0.804 \\
\hline & Palotina 1 & 0.149 & 0.165 & 0.230 & -0.897 & & 0.907 \\
\hline & Palotina 2 & 0.252 & 0.194 & 0.216 & -0.889 & & 0.938 \\
\hline & Sta. Terezinha do Itaipu & 0.273 & 0.616 & 0.311 & -0.312 & & 0.648 \\
\hline & S. Pedro do Iguaçu & 0.803 & 0.143 & 0.379 & -0.096 & & 0.819 \\
\hline
\end{tabular}

For harvest moisture of 2015 second-crop were considered 2 factors, capturing $83.65 \%$ of the total variability. In factor 1 the environments Campo Mourão, Cascavel 1, Mariluz 1 Palotina 1 and Santa Terezinha do Itaipu were grouped. In Factor 2 Cascavel 2, Mariluz 2 and São Pedro do Iguaçu were grouped, all with negative factor loadings.

The environments Campo Mourão, Cascavel 1, and Palotina 1 (Table 3), remained grouped in distinct factors for yield in the two years of evaluation, showing that they are information generators for selection for this characteristic.

For harvest humidity (Table 4) it is observed that the pairs of environments Campo Mourão and Cascavel 1 and Cascavel 2 and São Pedro do Iguaçu were grouped in the same factor in the two years of evaluation, characterizing a redundancy pattern. In contrast, the Santa Terezinha environment of Itaipu was isolated in factor 3 for the 2014 season, proving important for the selection for this trait, as it presents a unique result pattern for the mesoregions under study. 
Table 4. Environmental stratification, according to the factor analysis methodology, for crop humidity of corn hybrids in the 2014 and 2015 second-crop in West and Central West of Paraná.

\begin{tabular}{|c|c|c|c|c|c|}
\hline Season & Environment & Factor 1 & Factor 2 & Factor 3 & Communalities \\
\hline \multirow{9}{*}{2014} & Campo Mourão & 0.851 & 0.326 & -0.208 & 0.874 \\
\hline & Cascavel 1 & 0.806 & 0.163 & -0.386 & 0.825 \\
\hline & Cascavel 2 & 0.889 & 0.207 & -0.260 & 0.901 \\
\hline & Mariluz 1 & 0.136 & 0.961 & -0.046 & 0.945 \\
\hline & Mariluz 2 & 0.207 & 0.946 & -0.020 & 0.939 \\
\hline & Palotina 1 & 0.682 & 0.432 & -0.367 & 0.786 \\
\hline & Palotina 2 & 0.627 & 0.498 & -0.444 & 0.838 \\
\hline & Sta. Terezinha do Itaipu & -0.147 & -0.011 & 0.895 & 0.823 \\
\hline & S. Pedro do Iguaçu & 0.822 & -0.027 & 0.286 & 0.758 \\
\hline \multirow{9}{*}{2015} & Campo Mourão & 0.804 & -0.471 & & 0.868 \\
\hline & Cascavel 1 & 0.738 & -0.601 & & 0.906 \\
\hline & Cascavel 2 & 0.199 & -0.906 & & 0.861 \\
\hline & Mariluz 1 & 0.797 & -0.553 & & 0.941 \\
\hline & Mariluz 2 & 0.446 & -0.793 & & 0.828 \\
\hline & Palotina 1 & 0.823 & -0.255 & & 0.742 \\
\hline & Palotina 2 & 0.628 & -0.677 & & 0.852 \\
\hline & Sta. Terezinha do Itaipu & 0.797 & -0.250 & & 0.697 \\
\hline & S. Pedro do Iguaçu & 0.544 & -0.732 & & 0.832 \\
\hline
\end{tabular}

The repeated tests in the same environment were in the same cluster, for 2015 second-crop yield and 2014 second-crop harvest moisture, indicating similar responses, causing redundant results, not contributing to genotype differentiation and selection. Similar results were reported by Garbuglio et al. (2007), who working with factor analysis in summer corn, grouped the Ponta Grossa environment in different years into one factor, which, according to the authors, leads to infer that the genotypes had similar behaviors.

\section{Conclusions}

The sowing of experiments in the same municipality generated redundant information for yield and harvest moisture, not contributing to the selection of superior genotypes. The municipalities Campo Mourão, Cascavel and Palotina are information generators for selection aiming at yield. Santa Terezinha do Itaipu, São Pedro do Iguaçu and Mariluz are sources of results to complement genotype differentiation for yield.

The municipalities Campo Mourão, Cascavel, Mariluz, Santa Terezinha do Itaipu and São Pedro do Iguaçu are generators of information for selecting hybrids for crop moisture, but Campo Mourão and Cascavel have redundant results.

The environments of Campo Mourão, Mariluz, Santa Terezinha do Itaipu, Sao Pedro do Iguaçu Palotina and Cascavel are a good choice to evaluate yield and grain moisture loss for the West and Central West mesoregions of Paraná.

\section{References}

BATISTA, V.V.; ADAMI, P.F.; MORAES, P.V.; OLIGINI, K.F.; GIACOMEL C.L.; LINK. L. 2019. Row arrangements of maize and soybean Intercrop on silage quality and grain yield. Journal of Agricultural Science, 11(2):286-300.

BERGAMASCHI, H.; MATZENAUER, R. 2009. Milho. In: 'Agrometeorologia dos cultivos: O fator meteorológico na produção agrícola'. (Eds. JEBA MONTEIRO) pp. 239-260. Instituto Nacional de Meteorologia (INMET), Brasília, DF. 
CARVALHO, A.D.F.; SILVA, G.O.; PEREIRA, R.B.; PINHEIRO, J.B. 2014. Análise de fatores e regressão bissegmentada no estudo da adaptabilidade e estabilidade de cenoura. Revista Ceres, Viçosa, 61(6):932-940.

COCHRAN, W.G. 1954. The combination of estimates from different experiments. Biometrics, 10:101-129.

CRUZ, C.D. 2013. GENES - a software package for analysis in experimental statistics and quantitative genetics. Acta Scientiarum.Agronomy, 35(3):271-276.

CRUZ, C.D.; CARNEIRO, P.C.S. 2006. Modelos biométricos aplicados ao melhoramento genético. UFV, Viçosa, v.2, 585p.

DA ROCHA, D.R.; FORNASIER FILHO, D.; BARBOSA, J.C. 2011. Efeitos da densidade de plantas no rendimento comercial de espigas verdes de cultivares de milho. Horticultura Brasileira, Brasília, 29:392-397.

DIA, M.; WEHNER, T.C.; HASSELL, R.; PRICE, D.S.; BOYHAN, G.E.; OLSON, S.; TOLLA, G.E. 2016. Genotype $\times$ Environment Interaction and Stability Analysis for Watermelon Fruit Yield in the United States. Crop Science, 56(4):1645-1661.

FARIA, A.P.; MODA-CIRINO, V.; BURATTO, J.S.; SILVA, C.F.B. da; DESTRO, D. 2009. Interação genótipo $\mathrm{x}$ ambiente na produtividade de grãos de linhagens e cultivares de feijão. Acta Scientiarum.Agronomy, 31(4):579-585.

FRITSCHE-NETO, R.; MIRANDA, G.V.; DELIMA, R.O.; SOUZA, H.N. 2010. Factor analysis and SREG GGE biplot for the genotype $\times$ environment interaction stratification in maize. Ciência Rural, 40(5):1043-1048.

GARBUGLIO, D.D.; GERAGE, A.C.; ARAÚJO, P.M.; FONSECA JUNIOR, N. S.; SHIOGA, P.S. 2007. Análise de fatores e regressão bissegmentada em estudos de estratificação ambiental e adaptabilidade em milho. Pesquisa Agropecuária Brasileira, 42(2):183-191.

GRANATE, M.J.; CRUZ, C.D.; CECON, P.R.; PACHECO, C.A.P. 2001. A análise de fatores na predição de ganhos por seleção em milho (Zea mays L.). Acta Scientiarum.Agronomy, 23(5):1271-1279.

HARTLEY, H.O. 1950. The use of range in analysis of variance. Biometrika, 37:271-280.

INSTITUTO PARANAENSE DE DESENVOLVIMENTO ECONÔMICO E SOCIAL (IPARDES). 2003. Leituras regionais: Mesorregião Geográfica Oeste Paranaense. Instituto Paranaense de Desenvolvimento Econômico e Social, Curitiba. 143p.

INSTITUTO PARANAENSE DE DESENVOLVIMENTO ECONÔMICO E SOCIAL (IPARDES). 2004a. Leituras regionais: Mesorregião Geográfica Centro-Ocidental Paranaense. Instituto Paranaense de Desenvolvimento Econômico e Social, Curitiba. 133p.

INSTITUTO PARANAENSE DE DESENVOLVIMENTO ECONÔMICO E SOCIAL (IPARDES). 2004b. Leituras regionais: Mesorregião Geográfica Noroeste Paranaense. Instituto Paranaense de Desenvolvimento Econômico e Social, Curitiba. 141p.

JOHNSON, R.A.; WICHERN, D.W. Applied multivariate statistical analysis. 1992. Englewood Cliffs, New Jersey. 642p. 
MARTINELLI, A.P.; PEREIRA, R.S.B.; TAVARES, M.; ALBUQUERQUE, C.J.B. 2012. Adaptabilidade e Estabilidade de híbridos de milho em ambientes de safrinha na região central do Brasil. In: 'XXIX Congresso Nacional de Milho e Sorgo: Anais'. pp. 2764-2770. Águas de Lindóia, SP.

MELOTTO, A.M.; LAURA, V.A.; BUNGENSTAB, D.J.; FERREIRA, A.D. Espécies florestais em sistemas de produção em integração. 2019. In: 'ILPF: inovação com integração de lavoura, pecuária e floresta'.pp. 429-454. Embrapa, Brasília, DF.

MENDES, M.H.S.; RAMALHO, M.A.P. 2018. Repeatability of some phenotypic stability parameters - a resampling approach. Crop Breeding and Applied Biotechnology, 18(2):139147.

MENDONÇA, O.; CARPENTIERI-PÍCOLO, V.; GARBUGLIO, D.D.; FONSECA JUNIOR, N.S. 2007. Análise de fatores e estratificação ambiental na avaliação da adaptabilidade e estabilidade em soja. Pesquisa Agropecuária Brasileira, 42(11):1567-1575.

MURAKAMI, D.M.; CRUZ, C.D. 2004. Proposal of methodologies for environment stratification and analysis is genotype adaptability. Crop Breeding and Applied Biotechnology, 4:7-11.

PEREIRA, H.S.; COSTA, A.F. da; MELO, L.C.; PELOSO, M.J.D.; FARIA, L.C. de; WENDLAND, A. 2013. Interação entre genótipos de feijoeiro e ambientes no Estado de Pernambuco: estabilidade, estratificação ambiental e decomposição da interação. Semina: Ciências Agrárias, 34(6):2603-2614.

PEREIRA, H.S.; MELO, L.C.; FARIA, L.C. de; PELOSO, M.J.D.; WENDLAND, A. 2010. Estratificação ambiental na avaliação de genótipos de feijoeiro-comum tipo carioca em Goiás e no Distrito Federal. Pesquisa Agropecuária Brasileira, 45(6):554-562.

PIMENTEL-GOMES, F. 2009. Curso de estatística experimental. 15.ed. Fealq, Piracicaba, 451p.

RESENDE, M.D.V. 2015. Genética quantitativa e de populações. Suprema, Visconde do Rio Branco, MG.

RIBEIRO, J.Z.; ALMEIDA, M.I.M. 2011. Estratificação ambiental pela análise da interação genótipo x ambiente em milho. Pesquisa Agropecuária Brasileira, 46(8):875-883.

SANS, L.M.A.; GUIMARÃES, D.P. 2006. Zoneamento agrícola de riscos climáticos para a cultura do milho. Embrapa Milho e Sorgo, Sete Lagoas, MG.

SCAPIM, C.A; CARVALHO, C.G.P; CRUZ, C.D. 1995. Uma proposta de classificação dos coeficientes de variação para a cultura do milho. Pesquisa Agropecuária Brasileira, 30(5):683-686.

SEAB/DERAL. 2019. Secretaria de Agricultura e Abastecimento do Estado do Paraná. Departamento de Economia Rural. Tabela de produção agrícola por município. Available at: http://www.agricultura.pr.gov.br/modules/conteudo/conteudo.php?conteudo=137

SHIOGA, P.S.; GERAGE, A.C. 2010. Influência da época de plantio no desempenho do milho safrinha no estado do Paraná, Brasil. Revista Brasileira de Milho e Sorgo, 9(3):236-253. 
SHIOGA, P.S.; GERAGE, A.C.; ARAÚJO, P.M. de; BIANCO, R.; CUSTÓDIO, A.A. de P. 2014. Avaliação Estadual de Cultivares de Milho Segunda Safra 2014. Instituto Agronômico do Paraná - IAPAR. Boletim Técnico No 82, Londrina.

SHIOGA, P.S.; GERAGE, A.C.; ARAÚJO, P.M. de; BIANCO, R.; CUSTÓDIO, A.A. de P. 2015. Avaliação Estadual de Cultivares de Milho Safra 2014/2015. Instituto Agronômico do Paraná - IAPAR. Boletim Técnico No 85, Londrina.

SOUSA, L.B.; HAMAWAKI, O.T.; NOGUEIRA, A.P.O.; BATISTA, V.M.; HAMAWAKI, R.L. 2015. Evaluation of soybean lines and environmental stratification using the AMMI, GGE biplot, and factor analysis methods. Genetics and Molecular Research, 14(4):12660-12674. 